\section{FISCAL POLICY AND FISCAL RULES IN THE EUROPEAN UNION*}

\section{VITO TANZI**}

\section{Introduction}

In his revolutionary work, the godfather of modern fiscal policy, Lord Maynard Keynes, gave a central role to discretion in fiscal policy. Thus, in some ways, he, and even more his followers, who probably pushed his ideas beyond where he would have liked, gave policymakers what many of them had always wanted: a justification for spending more or, in particular cases, for reducing taxes without cutting public spending. A correct or effective discretionary fiscal policy is difficult to pursue because it requires information and attitudes that are often in short supply. When countries try to fine-tune their fiscal policy, they often end up making mistakes. This paper will focus on those difficulties within the European context. It will discuss problems that have not received the attention that they deserve. ${ }^{1}$

Since it was first proposed, and then endorsed by the Keynesians, with a revolutionary fervor that at times paralleled that of true religious believers, countercyclical fiscal policy has been subjected to occasional criticism. Three major lines of criticism can be distinguished.

First, there is the existence of various lags. It was noticed from the beginning that there are likely to be lags in: (a) the recognition that fiscal action is needed; (b) in the taking of the action; and (c) in the time that passes between when the action is taken and when the economy begins to feel its effects. These lags reduce the effectiveness of counter-cyclical policy. This criticism was frequently heard in the 1950s and the early 1960s but, although it is certainly valid and important, it seems to have largely disappeared from recent writings. A good discussion of the early criticism can be found in Stein (1969).

\footnotetext{
* Forthcoming in Europe after Enlargement, edited by Anders Aslund and Marek Dabronski (Cambridge University Press).

** Present affiliation, Senior Consultant, Inter-American Development Bank, Washington, D.C. The views expressed are personal ones.vitotanzi@msn.com

${ }^{1}$ Some of the issues discussed in this paper have been dealt with in some detail, for the Italian context, in Tanzi (mimeo, 2005).
}

The existence of lags may help explain why empirical studies of fiscal policy often find it to be procyclical rather than counter-cyclical. See for example, OECD (2004) and IMF (2004). It may be worthwhile to cite the IMF study: "Discretionary fiscal policies in Euro area countries over the past three decades have generally been pro-cyclical - that is, [they have been] expansionary in good times, contractionary in bad times - thereby undermining the role of automatic stabilizers." (p.111). This was a concern of those who stressed the significance of these lags. For other groups of countries, fiscal policy has also been found to be pro-cyclical. For example, a study of 104 countries found that "fiscal policy is procyclical (i.e. government spending increases in good times and falls in bad times ...);" see Kaminsky, Reinhart and Vegh (mimeo, September 2004). The citation is from the abstract to the paper. Gavin and Perotti (1997) found pro-cyclical fiscal policies for Latin American countries and Talvi and Vegh (2000) found pro-cyclical fiscal policy for the whole developing world.

Thus, the problem of pro-cyclicality seems to be common rather than the exception. However, that problem has not been related, in recent writings, to the existence of these lags. It has not reduced the policymakers' and economists' enthusiasm for fiscal discretion and for counter-cyclical fiscal policy. This enthusiasm is largely at the base of the attacks against the Maastricht rules, which are accused of impeding such a policy.

Second, there is the criticism associated with the socalled Ricardian equivalence. This criticism was often heard in the late 1970s and in the 1980s after Robert Barro reformulated and publicized a theory (first advanced by Ricardo) that had been well known in the Italian literature on public finance for a very long time; (see Barro, 1974). This theory assumes that individuals react to government deficits and public debt by increasing their own savings in anticipation of higher future taxes to repay the debt. By so doing, they may neutralize fully, or at least to some extent, the potential effect on the economy of the fiscal policy action.

There has been considerable controversy about the extent of this presumed reaction or compensation on the part of individuals. Some, including Vilfredo Pareto almost a century ago, have been skeptical that individuals have the foresight to anticipate future tax increases. However, while many econo- 
mists have rejected the notion of a full compensation, many would agree that there is some compensation. This is more likely to happen now, when the information about the existence of fiscal deficits and public debts is more generally available, than in Ricardo's times. A recent analysis, conducted by the OECD, has concluded that in OECD countries, "The evidence of partial, yet substantial, direct offsetting movements in private saving is strong. The aggregate initial offset is about half in the short term ... rising to around 70 percent in the long run;" see OECD (2004), p. 143.

The third line of criticism can be based on the observation that it is easier to find countries whose economies have grown faster after fiscal contractions than after fiscal expansions. It is, in fact, hard to find specific countries where a counter-cyclical fiscal policy led to a fast recovery from a cyclical downturn. Some would point to the United States after 2001, when record expansionary measures were taken by the Bush administration that, in the view of some observers and claims from the Bush administration, pulled the country out of the downturn. However, in 1993, the country came out of an even steeper downturn while contractionary fiscal measures were being taken, and the expansion of the 1990s became one of the longest in U.S. history. Furthermore, in 2001 to 2002, the Fed took extraordinary measures by reducing interest rates to historically low levels. Work by Giavazzi and Pagano (1996), followed by works by Alesina and Ardagna (1998), Schuknecht and Tanzi (2005) and others, have shown that fiscal contractions can be expansionary for a variety of reasons, but mainly because they reduce the worries about future fiscal developments, thus helping change the psychology of economic agents and investors. "Animal spirits" are certainly influenced by the psychological attitudes of individuals.

I would like to add one additional difficulty encountered in the pursuit of counter-cyclical fiscal policies. It is a difficulty, or criticism, based on public choice considerations. An implicit and fundamental assumption of countercyclical fiscal policy is that taxes and public spending can be changed with the same facility in both directions. Thus, there is no bias in the application of Keynesian policies. However, in reality, there is often asymmetry in the use of fiscal instruments, because it is generally far easier, politically, for governments to cut taxes and raise spending, than to do the reverse. This asymmetry tends to lead to structural fiscal deficits and to high debts even in normal periods, as the European experience indicates; see Tanzi (2004).

The above criticisms should have reduced the enthusiasm of many for the possibility of using countercyclical policy in the real world. But apparently they have not. The enthusiasm for discretionary fiscal policy remains strong. In this paper, I will not elaborate on the above criticisms. Rather, I will deal with issues that, though important, have received far less attention, perhaps because they require a kind of insider's knowledge not easily available to many economists who write papers on fiscal policy. These are issues of particular importance for European countries and especially for the application of the Stability and Growth Pact.

The rest of the paper is organized as follows. Section II describes the process by which fiscal rules have become progressively more relaxed over the years. They have lost their bite. Section III discusses problems of a practical nature that arise in the real life implementation of counter-cyclical fiscal policy. Section IV discusses briefly fiscal policy in the European Union. Finally, Section V summarizes the arguments and draws some conclusions.

\section{The progressive relaxation of fiscal rules}

As a consequence of the Keynesian "revolution," fiscal rules that had traditionally guided fiscal actions were dismissed as archaic or reflecting the views of "dead economists." The proponents of the Keynesian revolution were very critical, especially in the formative years of the 1950s and 1960s, when the "revolution" was in full swing, vis-à-vis these rules and vis-à-vis policymakers who still abided by them. For example, in 1958, James Tobin would state that, "[o]rthodox fiscal doctrines have ... dominated our policies ... and ... have brought the nation to the brink of catastrophe ... (Tobin, 1966, p. 57).

The "orthodox fiscal doctrines," alluded to by Tobin, that had guided fiscal policy, at least since Cicero's time, were the "balanced budget rule" and the belief that the level of public spending and of taxes should be as low as possible. These doctrines collided with the Keynesian view that the public sector should be larger and the budget did not need to be in balance. ${ }^{2}$

2 Citing again Tobin, "increased taxation is the price of growth" (ibid, p. 87); and citing Galbraith, the "conventional wisdom of balanced budgets ... [has become obsolete]," Galbraith (1958, p.18). 
Of course it had always been recognized that when exceptional events occurred, such as wars, major catastrophes, major public works and so on, the balanced budget rule could be broken and was broken. Over the centuries, these events had occasionally led to (temporary) tax increases and to debt accumulation. But, once normal times returned, the governments were expected to fully repay the debts they had accumulated by running fiscal surpluses, to reduce the exceptional spending and taxes, and, as soon as feasible, to return to the balanced budget rule. This "tax smoothing" was consistent with a rule that required zero debt and balanced accounts in normal times.

Keynes added the business cycle to the reasons that justify violation of the balanced budget rule. It should be noted, however, that he was writing during the Great Depression, an event that surely qualified as exceptional. ${ }^{3}$ The Keynesians added the normal business cycle (as distinguished from a depression) to the list of events that required the abandonment of the balanced budget rule. More recently, the policymakers who met in Brussels in March 2005 and modified the Maastricht arrangements on fiscal policy added, implicitly, a slowdown in economic growth (which is different from a cycle) to the list of events that can justify the abandonment of fiscal rules. ${ }^{4}$

Some policymakers have been arguing for special treatment, in the fiscal accounts, for a whole range of categories of public spending (public investment, $\mathrm{R} \& \mathrm{D}$, defense, contributions to the EU, expenditures for structural reforms) or even for reductions in public revenue due to tax cuts. They have argued that these expenditure increases or revenue reductions would justify larger fiscal imbalances. In their view, the measure of the fiscal deficit that should determine whether a country is in compliance with the general Maastricht rules should be corrected to reflect these fiscal actions. Thus, we have been witnessing a progressive slackening of the discipline that used to guide the policymakers in charge of fiscal policy. We seem to have gone from a straighjacket to one that may approach complete laxity. According to this thinking, the relevant gauge for assessing fiscal policy must be adjusted for the effect

\footnotetext{
${ }^{3}$ During the Great Depression, 25 percent of the American labor force was unemployed. GDP fell from $\$ 97$ billion in 1930 to $\$ 58$ billion in 1933. Between 1930 and 1941, when the United States entered the war, the fiscal deficit of the US government fluctuated between a surplus of 0.8 percent of GDP in 1930 to a deficit of 5.9 percent of GDP in 1934 . For other years, it was generally around 4 percent of GDP.

${ }^{4}$ In this case, the rule that would be compromised would be the one that constrains the deficit to three percent of actual domestic product.
}

of the cycle and for that of particular expenditures or even particular tax cuts.

The recent relaxation of the Maastricht rules is an almost natural extension of the relaxation of the balanced budget rule that started with the Keynesian revolution. In the early 1960s, a sophisticated version of the Keynesian counter-cyclical fiscal policy introduced the theoretically important distinction between actual revenue and expenditure and their cyclically adjusted counterparts; see The Economic Report of the [U.S.] President of 1962. According to this version, the actual budgetary outcomes could be compared with the counterfactual or virtual budgetary outcomes that would have occurred if the economy had been at its "potential." The differences between these variables would indicate whether current fiscal policy provided the needed stimulus or whether it was "deflationary" or "expansionary." It would thus signal whether some restrictive or stimulative policy action was needed. The theory assumed that potential income was a variable that could be estimated objectively (even though it existed only in its virtual form) and that its future growth could be forecast. One could project with some confidence, using past trends, how potential income would evolve in future years and use this projection for determining the needed discretionary fiscal action. ${ }^{5}$

A fiscal policy judged to be sound required a balance between the cyclically adjusted revenue and the cyclically adjusted public expenditure. In other words, it required a balanced budget rule applied to (unobservable) virtual variables. ${ }^{6}$ If these cyclically adjusted variables were not in balance, policy action was required. This policy could be used to stimulate the economy or to slow it down. ${ }^{7}$ If cyclically adjusted revenue exceeded cyclically adjusted expenditure, fiscal policy would justify more spending or less taxation. If the reverse were true, fiscal action would promote less spending or higher taxes. A cyclically adjusted budget that was balanced would, thus, be consistent with an (actual) fiscal deficit in a recession (when "potential" income fell below actual income) and a fiscal surplus during a boom (when actual income exceeded "potential" income).

\footnotetext{
${ }^{5}$ At that time, American economists believed that business cycles were well behaved. There were courses on business cycles in universities and these courses explained the average length of cycles and their average amplitude. Also, productivity growth was assumed to be largely a constant.

${ }^{6}$ That is, it required fiscal balance at potential income.

${ }^{7}$ By the way, the role of monetary policy in this context was always vague.
} 
Built-in stabilizers would make the response of fiscal variables to the cycle more accentuated. They would create larger surpluses in boom time and larger deficits in recession and help reduce the amplitude of the cycles. There was a push in the 1960 s to make income taxes more progressive and the taxes on corporations more important because these taxes reacted more to fluctuations in income helping to stabilize the economy. The sensitivity of the tax system to changes in income was a variable that received much attention in the 1960s and 1970s; see for example Tanzi (1969) and Tanzi and Hart (1972). Flat rate taxes and low taxes on enterprises now in fashion, especially in the new market economies of Europe, would reduce the built-in stabilizing properties of the fiscal variables and require larger discretionary actions during business cycles.

A "cyclically-neutral" fiscal policy, applied faithfully and correctly, would produce a zero fiscal deficit over the cycle and, thus, would not lead to long-term debt accumulation. The debt accumulated during a recession should be repaid during the upswing. However, with rare exceptions (Luxembourg, Norway, Estonia), countries have ended up with large public debts, even in periods when no major wars, depressions, catastrophes, or big pushes in public works have occurred. This is evidence, if one were necessary, that more constraining fiscal rules are needed. Large public debts divert valuable tax resources toward the servicing of the debt and make it more difficult for countries to have their fiscal accounts in balance. There is some empirical evidence that interest payments on public debts reduce public investment; see Tanzi and Chalk (2000).

Some European countries' authorities have, on the one hand, argued that the high public debt makes it difficult for the country to have good fiscal accounts. On the other hand, they have supported the push towards more fiscal relaxation that could easily lead to the further accumulation of public debt. Furthermore, when public debt is towards foreigners, the cost of servicing it becomes higher and the potential danger associated with it also grows. For economies that had been centrally planned, the public debt is often foreign debt, because they do not have developed domestic financial markets. For these countries, the sustainable public debt is likely to be lower than in more advanced countries with more developed financial institutions; see Coricelli (2005).

\section{Pitfalls in the implementation of discretionary} policy

Surprisingly, while the theory of counter-cyclical fiscal policy has received a lot of attention over the years, and is routinely taught in economics courses, its implementation has received very little attention. The view must be that what is true in theory must be correct and feasible in practice. Or, alternatively, it is possible that those who teach the theory are not fully aware of the many difficulties faced in its implementation. ${ }^{8}$ In the rest of this paper, I will focus on the practical implementation of the theory. I have little difficulties with the theory itself. In a perfect world, I would want to follow it. But then a perfect world would not have economic fluctuations.

Cyclically adjusted fiscal policy compares actual variables (revenue, expenditure, fiscal deficits and even public debt) with counterfactual variables, that is with variables that are not observed and that must, somehow, be estimated as if they existed. This is far more difficult than is assumed. In this process, mistakes tend to creep in, and they may not always be honest or random errors. Furthermore, even the measurement of actual current fiscal variables has proven to be difficult, as Eurostat, now, and the IMF, over many years, have found out. ${ }^{9}$ Thus, it is easy to imagine the difficulties that exist in estimating counterfactual variables. The issues discussed below are complex. They would deserve a more extensive treatment. But I hope to convey a sense of the difficulties. I will discuss first the technical requirements for adopting a counter-cyclical fiscal policy and then focus briefly on political difficulties.

Consider first the technical requirements:

First, a counter-cyclical policy requires the estimates of "potential" income for the current and relevant future periods. How far is the actual income from the potential income? The theoretical literature assumes that the question can be answered easily. Unfortunately, this is not the case. Business cycles are not well behaved and it is difficult or impossible to determine whether current changes in the growth of income reflect the effect of a genuine business cycle or a change in trend caused by structural obstacles. A

${ }^{8}$ Once again, I am ignoring here the difficulties connected with lags that did receive attention. I am also ignoring the theoretical criticism associated with the so-called Ricardian equivalence. This critcism dominated the economic literature in the 1980s, but it seems to have almost disappeared from recent discussions.

${ }^{9}$ Eurostat has recently made embarrassingly large revisions to the deficit estimates for some countries (Greece, Italy) for past years. The IMF has often discovered that the deficits reported for some countries were substantially wrong. 
good example of this difficulty is provided by Japan. A decade or so ago, when the Japanese economy slowed down, the IMF and the OECD mistook the change in that country's income for a cyclical slowdown, rather than a change in trend. Thus, these organizations strongly and vocally recommended expansionary fiscal policies to inject additional demand. After some hesitations, the Japanese endorsed the recommendation. The result has been that a country that in the early 1990s had by far the best fiscal accounts among OECD countries now has the worst, with a public debt that is 170 percent of GDP and a gaping fiscal deficit that gives no sign of shrinking. This sharp deterioration in the fiscal accounts (a) did not produce any positive effects on the real economy and (b) is likely to constitute a major obstacle to the future growth of that economy. ${ }^{10}$ Are we confident that the recent slowdown in several European countries, and especially in the large ones, is part of a cycle and not the beginning of a new slower growth trend? And are we confident that a relaxation of the Maastricht constraints will stimulate growth and not repeat the Japanese mistake?

Second, the pursuit of a correct counter-cyclical policy requires that the effect of the cycle on the fiscal accounts can be isolated from the effect of discretionary changes on the revenue and the expenditure sides of the budget. Most economists do not appreciate how difficult it is to isolate changes in fiscal variables due to discretionary measures (including those of an administrative character) from those due to the cycle. In many countries, this separation is impossible to make, but it is still reported. In many countries, discretionary changes, either of a policy type or, more often, of an administrative type, take place all the time. Especially tax administrations are very active and their activities can have significant effects on tax revenue.

This is an area where the US experience has influenced thinking. In the United States, until recent years, and especially on the tax side, there were few if any discretionary changes in most years. Only infrequent tax reforms introduced such changes. The Internal Revenue Service is required to administer the taxes in a consistent way. The policy changes come at discrete times and are highly advertised. Thus, cyclical adjustments that might have had some

${ }^{10}$ Also, the emphasis on the fiscal expansion and the pressure on the Japanese coming from the international organizations and from the G-7 countries distracted the Japanese authorities from the major obstacles to growth that were structural in nature. The statements of the G-7 always emphasized the need for a fiscal expansion over the need for structural reforms. justification when applied to the United States have been applied to countries with very different situations. In the footnote to the table that reports the output gap relative to potential GDP, the European Commission cautions that, "Output gaps are often non-observable concepts and can be measured in different ways. Analysis based on them should be treated with prudence." The IMF warns that, "Estimates of the output gap and of the structural balance are subject to significant margins of uncertainty." 11 Unfortunately, they do not seem to be treated with "prudence", and the "significant margins of uncertainty" are ignored.

Third, the pursuit of a correct counter-cyclical policy requires the availability of well-established and robust quantitative relationships between public revenue or public spending, on one side, and national income, on the other. These relationships must have been estimated for long periods of time by netting out the effects of discretionary actions, which, as already stated, is often almost impossible to do. These relationships have proven unstable in various situations, as for example in the later years of the Clinton administrations when the profits from the "new economy" distorted tax revenues. Recently, they have also proven unstable in the UK and Germany. Therefore, past relationships may be poor predictors of future relationships even in the absence of discretionary changes. When these estimates of past relationships are based on only a few years, as it must be the case for new members of the European Union, they would be particularly suspect.

Finally, the pursuit of counter-cyclical fiscal policy requires a precise determination of where a country is at a given moment. What is its true current fiscal situation? ${ }^{12}$ Unfortunately, as strange as it may sound, definitive, objective measures of current revenue, spending, fiscal deficit, and even income are often not available. There are practical or even conceptual difficulties in providing these measures and ex post changes in the measures are common and at times embarrassingly large.

Estimates of the fiscal deficit were traditionally based on cash payments to and from the government. These are the easiest to calculate when all the flows can be controlled. That is when there are no extra budgetary flows. However, they lend them-

11 See IMF (September 2004, p. 188).

12 The fact that this question is now being asked almost daily in countries such as the United States, Italy, Germany and so on indicates that the question is not rhetorical. 
selves to maneuvers aimed at making the deficits look smaller for given periods, and at times do not cover the whole public sector, but only a part of it. Partly for the first of these reasons and partly because "accrual" concepts are supposed to better reflect the time when the measures have an impact on the real economy, statisticians tend to prefer measures based on accrual concepts. Eurostat has favored accrual measures. These, however, are not easy to determine and often can only be determined with considerable lags. ${ }^{13}$ Also, there remain several grey areas in the Eurostat methodology that create debates and invite interpretation on the part of the countries' experts. ${ }^{14} \mathrm{~A}$ consequence has been that large "revisions" to the estimates are often made years after the data have been provided by the governments. In particular cases (Greece and Italy), these revisions have amounted to several percentage points of GDP. Unfortunately, the revisions are in one direction. They all raise the size of the fiscal deficit suggesting that the errors may not have been purely random. Because of political pressures, the incentives for the national experts have been to interpret the Eurostat rules in ways that tend to reduce the size of the fiscal deficits.

A related point is that in some cases, as in Italy, there have been uncomfortably wide differences between the cash measure of the fiscal deficit and the accrual or, better, Eurostat measure. Furthermore, there have been differences even between supposedly conceptually identical definitions, but measured by different institutions. This raises two questions: First, which measure of the deficit is the correct one? Second, which is the one relevant for the pursuit of a counter-cyclical policy? When one measure gives a deficit of, say, two percent of GDP and another a deficit of, say, four or five percent of GDP, which measure should drive counter-cyclical fiscal policy? Unfortunately, these questions have been largely ignored by economists, even though they are fundamental to the conduct of counter-cyclical policy.

Consider now the political requirements of an effective counter-cyclical policy. Political cycles must not be present; elections must not influence the fiscal decisions of governments; there must be no incentive to present biased data; and there must not be any incentive to manipulate the data through "financial engineering" or through once-for-all (una tantum)

${ }^{13}$ This, for example, is the case of health expenditure in Italy.

14 The Eurostat methodology is still partly dependent on cash flows and thus it is not purely accrual. measures. Unfortunately, tax amnesties; sales of public assets; creation (à la Enron) of extra budgetary accounts to which some debt is shifted; the assumption of contingent liabilities on the part of the government not shown in the accounts; attempts to push some institutions outside of the budget; postponement of some payments, as for example tax refunds, to creditors; anticipation of some future revenue, for example by pressuring some enterprises in which the government has a controlling interest to anticipate the distribution of dividends; and so on, are only too frequent occurrences, as various papers and the events of some countries have shown; see Koen and den Noord (2005); and Brixi (2005). "Financial engineering" has come to strongly influence fiscal policy. In the ministries of finance of some countries, "financial engineers" have replaced, in influence at least, traditional fiscal experts. Their role is to "package" the financial accounts to make them look better than they are. Unfortunately, some policymakers seem to be more interested in making the accounts look good than at genuinely improving them. At times, they lose the ability to distinguish the genuine accounts from the "packaged" ones.

Add to all of this the view, now popular with some policymakers, that fiscal deficits are good for growth (and not just to help a country get out of a temporary recession) and it is easy to see the potential problems encountered when a broadly defined "balanced budget rule" is abandoned. The problems mentioned above become greater when flexibility is introduced in a rule that already allows fiscal deficits of three percent of GDP and public debts of 60 percent or more of GDP. It would be better if the rule required a zero fiscal deficit and a zero public debt as the normal objective recognizing that this objective could not be achieved every year or immediately by countries that started their membership in the European Union by being far from it. The flexibility should be in the speed of transition toward a zero deficit and a near zero public debt and not vis-à-vis much less ambitious goals. When a three percent deficit and a 60 percent debt, as proportions of GDP, are allowed, these tend to become the minimum, as it has happened recently.

\section{Fiscal policy in the EU}

The abandonment of a strict interpretation of the whole package of Maastricht rules (excessive deficit provision and procedure plus the Stability and 
Growth Pact proper) signals a worrisome trend. A few years from now we may be lamenting the recent decisions by the Council of Ministers. But, by that time, other ministers would be on the scene and would suffer the consequences of the March 2005 decision taken by their predecessors.

The pre-Maastricht period was fiscally friendly. There were no wars, no major catastrophes, and no major depressions in EU countries. There was yet no fiscally unfriendly aging of the population and no, or little, negative impact on tax revenue coming from tax competition and globalization. The economic competition from lower spending and lower taxing countries (China, India, Mexico, other countries from South East Asia) was still very limited. Therefore, in this fiscally friendly, pre-Maastricht period, one would have expected healthy fiscal outcomes for European countries. One statistic is sufficient to convey a sense of fiscal developments in that period. For the $12 \mathrm{EU}$ countries combined, the share of public debt in GDP rose from 31 percent in 1977 to 75.4 percent in 1997 ! This was a phenomenal change that took place in a fiscally friendly period. ${ }^{15}$ With all its faults and possible tricks, Maastricht brought that growth to a temporary stop. Before Maastricht, some among the 12 EU countries were risking to go the Argentine way. The growth in public debt seems to have started again and from a much higher level. Such growth, combined with, or promoted by, higher interest rates, could create a truly worrisome debt dynamic.

The bad experiences of many countries with fiscal outcomes, both within and outside Europe, have brought back some interest in fiscal rules. Many different rules have been proposed and some have been introduced into the laws or the constitutions of some countries, including the Netherlands and Poland. But these rules remain controversial because they go against the political and short-run interests of policymakers, who worry about the next elections, and against the entrenched intellectual beliefs of many economists, who have spent too little time in the real world and too many in the Keynesian world. In some way, as Milton Friedman once remarked, at some point, we all became Keynesians. This often means that, when we come to fiscal policy, we pay little attention to structural impediments to growth and we put our faith in an active fiscal policy.

15 In the three largest countries of the EU, the debt share of GDP rose as follows: from 26.8 to 61.0 percent in Germany; from 20.1 to 59.3 percent in France; and from 56.4 to 120.2 percent in Italy.
Unfortunately, this policy is often implemented from a position in which the fiscal accounts are already in difficulty and they are already sending worrisome signals to the public. At this point, counter-cyclical fiscal policy is not likely to do much good because whatever stimulative effect it may have on consumers is balanced by the negative effects on investors and economic agents that originate from and accompany deteriorating fiscal accounts. When, for example, a government wants to stimulate an economy by spending more or taxing less, but the message that economic agents receive daily is that the discretionary action will make precarious fiscal accounts even more precarious, why should we expect a positive impact from the fiscal action?

The introduction of fiscal rules runs, of course, into the problem of different initial positions. Two countries that have very different fiscal situations cannot be expected, overnight, to move to identical fiscal outcomes. This was, especially, the situation on the public debt in 1997 because of the high debts of Italy, Belgium and Greece. It may be the situation on the fiscal deficit today for Poland, Hungary and some other countries, which start with higher fiscal deficits. Thus, flexibility is required as to the time needed to conform to the rule, but the rule should not be relaxed to the point of making sinning more acceptable for everyone.

\section{Concluding remarks}

Theories may experience cycles just as economies do. They may be popular at some point in time, then lose their popularity to regain it once again. This seems to have happened to counter-cyclical fiscal policy. The theory became popular in the 1950s and especially in the 1960s. It started to lose some popularity in the 1970s, because of stagflation and the various intellectual attacks on it that came with the Ricardian equivalence, with rational expectation theories, with the implication of the permanent income hypothesis, with technologically based real business cycles, and so on. By the 1980s, that theory seemed to be under retreat. More recently, however, it has made a comeback especially, but not only, at the political level. Political figures have used it to justify more spending, or even cutting taxes, on the grounds that these actions would stimulate growth. In part, the attacks against the Stability and Growth Pact have been justified largely on Keynesian grounds. 
The new popularity of this theory is puzzling mainly because it is difficult to find countries where it has clearly worked. In fact, it is easier to find countries where fiscal consolidation seems to have promoted healthier economic performance. Fiscal consolidation may reduce worries and concerns about the future and may stimulate economic decisions that promote growth. However, the promotion of fiscal stimuli, through increases in public spending or cuts in taxes, in situations when the fiscal accounts are already in a precarious state (with high public debts and large fiscal deficits), is likely to produce negative reactions from investors and the public in general. This is especially the case in a world where fiscal policy is continually discussed in the media so that the worries of experts become general worries.

This paper has discussed some of these issues. However, the main focus of the paper has been to show that the pursuit of counter-cyclical fiscal policy is, on technical or practical grounds, much more difficult than it is normally assumed, even by economists. Often, the needed information is not available and the variables often used (potential income, structural balance, fiscal reaction functions, etc.) depend on assumptions that are often wrong.

Counter-cyclical fiscal policy should not be abandoned in depressions and it could be tried in milder slowdowns when the fiscal accounts of a country are in good initial conditions (deficit close to balance, debt close to zero). However, there are strong doubts on whether it should be tried by countries that have their fiscal accounts already in precarious conditions. In the view of this writer, fiscal accounts with public debts of 60 percent of GDP and fiscal deficits at three percent of GDP are in a precarious stage.

The implications of this conclusion for the Stability and Growth Pact are obvious. But the problem remains of how to introduce more conservative fiscal rules in a situation where the initial conditions are widely divergent and the political decision is to encourage countries to join a monetary union and not wait until their accounts are under control. The paper has concluded that the countries should be given more time to converge rather than relax the long-term standards, as it was done in the March meeting of European ministers. But of course, how to do this needs a lot more thinking.

\section{References}

Alesina, Alberto and S. Ardagna, 1998, "Tales of Fiscal Contractions," Economic Policy, No. 27.

Barro, Robert, 1974, "Are Government Bonds Net Wealth?," Journal of Political Economy, Vol. 82.

Brixi, Hana Polackova, 2005, "Contingent Liabilities in New Member States," (Mimeo, January 6).

Coricelli, Fabrizio, 2005, "Fiscal Policy and the Adoption of the Euro for New EU Members" (mimeo).

Council of Economic Advisers, 1962, Economic Report of the President (Washington, D.C.)

Galbraith, John Kenneth, 1958, The Affluent Society (Boston: Houghton Mifflin).

Gavin, Michael and Roberto Perotti, 1997, "Fiscal Policy in Latin America, " NBER Macroeconomics Annual (Cambridge, MA: MIT Press) pp. 11-61.

Giavazzi, Francesco and M. Pagano, 1996, "Non-Keynesian Effects of Fiscal Policy Changes: International Evidence and Swedish Experience," Swedish Economic Policy Review, Vol. 3.

IMF, 2004, World Economic Outlook, especially Chapter II, pp. 103-120.

Kaminsky, Graciela L., Carmen M. Reinhart, and Carlos A. Vegh, 2004, "When It Rains, It Pours: Procyclical Capital Flows and Macroeconomic Policies." (mimeo, September).

Koen, Vincent and Paul van den Noord, 2005, "Fiscal Gimmickery in Europe: One-off Measures and Creative Accounting," Economics Department Working Papers, Nw. 416 (OECD, Feb. 10)

Kopits, George, 2001, "Fiscal Rules, Useful Policy Framework or Unnecessary Ornaments?," IMF Working Paper, WP/01/145.

OECD, 2004, Economic Outlook, especially Chapter V, pp. 141-157 Volume 2004/2, Number 76, December.

Schuknecht, Ludger and Vito Tanzi, 2005, "Reforming Public Expenditure in Industrialized Countries: Are There Trade Offs?," ECB Working Paper Series No. 435, (February).

Stein, Herbert, 1969, The Fiscal Revolution in America (Chicago: University of Chicago Press).

Talvi, Ernesto and Carlos A. Vegh, 2000, "Tax Base Variability and Procyclical Fiscal Policy," NBER Working Paper No. 7499, forthcoming in Journal of Development Economics.

Tanzi, Vito, 1969, "Measuring the Sensitivity of the Federal Income Tax from Cross-Section Data," Review of Economics and Statistics (May).

Tanzi, Vito, and Tom Hart, 1972, "The Effect of the 1964 Tax Reform on the Sensitivity of the US Individual Income Tax," Review of Economics and Statistics (August).

Tanzi, Vito, 2004, "The Stability and Growth Pact: Its Role and Future," Cato Journal, Vol. 24, Nos. 1-2 (Spring/Summer).

Tanzi, Vito, 2005, "Fiscal Policy: When Theory Meets Reality," (mimeo).

Tanzi, Vito, and Nigel Chalk, 2000, "Impact of Large Debt on Growth in the EU: A Discussion of Potential Channels," European Economy (No. 2) pp. 23-43.

Tobin, James, 1966, National Economic Policy: Essays (New Haven: Yale University Press) 